\title{
PENDAPATAN USAHA BUDIDAYA IKAN NILA (Oreochromis $s p$ ) DALAM KERAMBA JARING APUNG DI DESA PEMATANG JERING KECAMATAN JAMBI LUAR KOTA KABUPATEN MUARO JAMBI
}

\author{
${ }^{1}$ Wiwin Alawiyah dan ${ }^{2}$ Rizki Yuliasari \\ ${ }^{1}$ Program Studi Agribisnis Fakultas Pertanian Universitas Batanghari Jambi \\ ${ }^{2}$ Alumni Program Studi Agribisnis Fakultas Pertanian Universitas Batanghari Jambi \\ J1. Slamet Riyadi-Broni, Jambi. 36122. Telp. +622251193244 \\ ${ }^{1}$ Email koresponden : rizkiyuliasari6@gmail.com
}

\begin{abstract}
Pematang Jering Village, Jambi Luar Kota, Muaro Jambi Regency is one of the villages that develops the fisheries sector in the floating net cages with high production yields. The purpose of this study is to describe the cultivation of tilapia in fish (KJA), as well as calculate the income of farmers in tilapia fish farming (KJA) in Pematang Jering Village, Jambi Luar Kota, Muaro Jambi Regency. This study uses a survey method carried out in Pematang Jering Village where the village is a place to grow tilapia. The number of samples taken in this study were 33 farmer households (RTP) of the total population in the village of Pematang Jering as many as 165 (RTP). By using the simple random sampling method chosen randomly by lottery, it can provide equal opportunities for members of the population to be selected as samples. From the results of the study showed that the average total cost was Rp.98,870,758.95 /period. Consisting of fixed costs Rp.5,933,088.64 /period and variable costs Rp.92,937,670.31/period. The average income received by farmers amounted to Rp.179,933,380/period, with an average income of Rp.81,062,621.05 /unit (KJA) in one maintenance period. Keywords : Income, Farming, Parrot fish
\end{abstract}

\begin{abstract}
Abstrak
Desa Pematang Jering Kecamatan Jambi Luar Kota Kabupaten Muaro Jambi merupakan salah satu desa yang mengembangkan sektor perikanan dalam Keramba Jaring Apung (KJA) dengan hasil produksi cukup tinggi. Tujuan dari penelitian ini untuk menggambarkan usaha budidaya ikan nila dalam (KJA), serta menghitung pendapatan petani usaha budidaya ikan nila dalam (KJA) di Desa Pematang Jering Kecamatan Jambi Luar Kota Kabupaten Muaro Jambi. Penelitian ini menggunakan metode survey. Jumlah sampel yang di ambil dalam penelitian ini adalah 33 rumah tangga petani (RTP) dari seluruh jumlah populasi yang ada di Desa Pematang Jering sebanyak 165 (RTP), dengan penggunaan metode simple random sampling, maka dapat memberikan peluang yang sama bagi anggota populasi untuk dipilih menjadi sampel. Hasil penelitian menunjukkan bahwa rata-rata total biaya adalah sebesar Rp.98.870.758,95/periode. Terdiri dari biaya tetap Rp.5.933.088,64/periode dan biaya tidak tetap Rp.92.937.670,31/periode. Rata-rata penerimaan yang diperoleh petani sebesar Rp.179.933.380/periode, dengan rata-rata pendapatan Rp.81.062.621,05/ unit (KJA) dalam satu periode pemeliharaan.
\end{abstract}

Kata Kunci : Pendapatan, Budidaya, Ikan Nila

Diterbitkan oleh Program Studi Agribisnis Fakultas Pertanian Universitas Batanghari Jambi Halaman 84 


\section{PENDAHULUAN}

Perkembangan perikanan budidaya berdasarkan Jumlah produksi dan nilai budidaya di keramba menurut jenis ikan di Provinsi Jambi menunjukkan bahwa ikan nila merupakan salah satu komoditas perikanan budidaya yang mengalami persentase peningkatan rata-rata produksi cukup tinggi. Hal tersebut dapat dilihat bahwa jumlah total produksi dan nilai budidaya di keramba ikan nila pada tahun 2017 memiliki total jumlah mencapai 10.995,73 ton. Ikan nila merupakan salah satu jenis ikan air tawar yang sudah di budidayakan secara komersial oleh masyarakat Indonesia salah satu nya di Provinsi Jambi (Dinas Kelautan dan Perikanan Provinsi Jambi, 2018).

Kecamatan Jambi Luar Kota merupakan salah satu kecamatan di Kabupaten Muaro Jambi yang mengembangkan sektor perikanan ikan nila dengan hasil produksi cukup tinggi dibandingkan dengan kecamatan lainnya. Di kecamatan Jambi Luar Kota terdapat 19 desa dan 1 kelurahan. Salah satu Desa Pematang Jering sebagai penghasil ikan nila. Ikan nila bernilai positif bagi masyarakat selain memberikan sumbangan pendapatan petani yang mengusahakannya, budidaya ikan nila juga mampu menyediakan lapangan pekerjaan bagi petani yang tidak memiliki usaha perikanan.

Desa Pematang Jering memiliki produksi ikan nila dalam kerambah jaring apung sebesar 4.100 Ton merupakan yang tertinggi dibandingkan dengan desa yang lain seperti Desa kedemangan merupakan yang terendah memiliki produksi ikan nila dalam keramba jaring apung sebesar 100 ton. Hal ini yang membuat penulis tertarik untuk melakukan penelitian yang berjudul "Pendapatan Usaha Budidaya Ikan Nila (Oreochromis sp) Dalam Keramba Jaring Apung Desa Pematang Jering Kecamatan Jambi Luar Kota Kabupaten Muaro Jambi”.

\section{METODOLOGI PENELITIAN}

Penelitian dilakukan terhadap petani pelaku budidaya ikan nila dalam keramba jaring apung di Desa Pematang Jering Kecamatan Jambi Luar Kota.Dipilihnya daerah Desa Pematang Jering Kecamatan Jambi Luar Kota Kabupaten Muaro Jambi sebagai lokasi penelitian adalah Desa Pematang Jering merupakan sentra budidaya ikan nila dalam keramba jaring apung yang jumlah produksinya tertinggi di Kecamatan Jambi Luar Kota dengan hasil produksi 4.100 ton . Pengambilan data penelitian dilaksanakan pada bulan Mei sampaiJuni Tahun 2019. Penelitian ini dibatasi pada kajian gambaran kegiatan usaha budidaya ikan nila dalam keramba jaring apung (KJA) dan pendapatan petani budidaya ikan nila dalam (KJA). Adapun jenis data yang digunakan berdasakan waktu adalah metode cross section atau satu waktu tertentu yang di ambil pada periode terakhir. Data cross section adalah data yang dikumpulkan dari satu waktu tertentu pada beberapa objek dengan tujuan untuk menggambarkan keadaan. Jenis data menurut skala ukur adalah jenis data Rasio.

Sumber data yang digunakan dalam penelitian ini adalah data primer dan data sekunder, baik yang bersifat kualitatif maupun kuantitatif. Data primer diperoleh langsung dari masing-masing petani budidaya ikan dalam keramba jaring apung di daerah penelitian dan data sekunder adalah data penunjang untuk

Diterbitkan oleh Program Studi Agribisnis Fakultas Pertanian Universitas Batanghari Jambi Halaman 85 
mendukung data primer, yang di peroleh dari berbagai literatur dan dokumen yang berkaitan dengan kegiatan penelitian.

Metode yang digunakan dalam penelitian ini adalah metode survei, (Sugiono, 2011) metode survei digunakan untuk mendapatkan data dari tempat tertentu yang alamiah (bukan buatan). Peneliti juga melakukan perlakuan dalam pengumpulan data, seperti mengedarkan kuisioner, wawancara berstruktur, dan sebagainya. Winarno (1994), bahwa untuk pedoman umum saja dapat dikatakan bahwa apabila populasi cukup homogen, terhadap populasi dibawah 100 dapat digunakan sampel sebesar 50\% dan apabila populasi diatas 100 dapat diambil sampel sebesar $15 \%$ dan sampel manusia ukuran diatas 30 orang.Jumlah petani yang melakukan kegiatan budidaya ikan nila dalam keramba jaring apung di Desa Pematang Jering Kecamatan Jambi Luar Kota Kabupaten Muaro Jambi tahun 2019 sebanyak 165 rumah tangga petani (RTP) 1 adalah 33 RTP atau sebesar 20\% dari total petani budidaya ikan nila, yang dipilih secara acak (simple random sampling). Penggunaan metode simple random sampling dapat memberikan peluang yang sama bagi anggota populasi untuk dipilih menjadi sampel (Singarimbun, 1982).

Untuk menghitung besarnya jumlah biaya produksi atau total cost (TC) dianalisis dengan cara menjumlahkan total biaya tetap atau total fixed cost (TFC) dalam rupiah per periode, ditambahkan dengan total biaya tidak tetap atau total variabel cost (TVC) dalam rupiah per periode, sesuai dengan rumus Sudarman dan Algifari (2001) :

$\mathrm{TC}=\mathrm{TFC}+\mathrm{TVC}$

Keterangan :

$\mathrm{TC} \quad=$ Total Biaya atau Total Cost $(\mathrm{Rp} /$ Periode $)$

TFC = Total Biaya Tetap atau Total Fixed Cost (Rp/Periode)

TVC = Total Biaya Variabel atau Total Variabel Cost (Rp/Periode)

Untuk menghitung besarnya penerimaan yang diperoleh dapat digunakan rumus sebagai berikut Menurut Samuelson dan Nordhaus dalam Bayu Pratama (2017) :

$\mathrm{TR}=\mathrm{Pq} \cdot \mathrm{Q}$

Keterangan :

$\mathrm{TR}=$ Total Penerimaan atau Total Revenue $(\mathrm{Rp} /$ Periode $)$

$\mathrm{Pq} \quad=$ Harga Produk $(\mathrm{Rp} / \mathrm{Kg})$

$\mathrm{Q} \quad=$ Jumlah Produksi $(\mathrm{Rp} / \mathrm{Kg})$

Untuk menghitung besarnya biaya tetap, dihitung berdasarkan nilai penyusutan alat yang digunakan, menggunakan rumus sebagai berikut (Sudarman dan Algifari, 2001) : 
$B P A_{\mathrm{i}}=\frac{D_{\mathrm{i}}-S_{\mathrm{i}}}{N_{\mathrm{i}}}$

Keterangan :

$\mathrm{BPA}_{\mathrm{i}}=$ Biaya Penyusutan Alat (Rp/periode)

$\mathrm{D}_{\mathrm{i}} \quad=$ Nilai Perolehan $(\mathrm{Rp} / \mathrm{Unit})$

$\mathrm{S}_{\mathrm{i}} \quad=$ Nilai Sisa $(\mathrm{Rp} /$ periode) $($ Asumsi 0$)$

$\mathrm{N}_{\mathrm{i}} \quad$ = Umur Ekonomis (Periode)

Untuk menghitung pendapatan diperoleh dengan cara mengurangkan total penerimaan dengan total biaya, dengan rumus sebagai berikut menurut (Boediono, 1992) :

$\mathrm{I}=\mathrm{TR}-\mathrm{TC}$

Keterangan :

I = Income atau Pendapatan $(\mathrm{Rp} /$ Periode $)$

$\mathrm{TR}=$ Total Revenue atau Total Penerimaan (Rp/Periode)

$\mathrm{TC}=$ Total Cost atau Total Biaya (Rp/Periode)

\section{Identitas Petani}

\section{HASIL DAN PEMBAHASAN}

\section{Umur Petani}

Umur petani merupakan faktor yang penting dalam proses usaha budidaya ikan. Produktivitas kerja sangat dipengaruhi oleh umur petani budidaya. Pada usia produktif produktivitas kerjanya akan lebih cepat dibandingkan dengan usia non produktif (Suharjo dan Patong, 1973).Di Desa Pematang Jering umur petani berkisar antara umur 22 sampai 63 tahun. Dengan rata-rata 38 Tahun. Untuk lebih jelasnya distribusi frekuensi petani berdasarkan umur dapat dilihat pada Tabel 1 berikut ini.

Tabel 1. Distribusi Frekuensi Petani Berdasarkan Umur di Desa Pematang Jering Tahun 2019.

\begin{tabular}{cccc}
\hline No & Kelompok Umur(Tahun) & Frekuensi(RTP) & Persentase(\%) \\
\hline 1. & $22-28$ & 9 & 27,27 \\
2. & $29-35$ & 7 & 21,21 \\
3. & $36-42$ & 8 & 24,24 \\
4. & $43-49$ & 3 & 9,09 \\
5. & $50-56$ & 1 & 3,03 \\
6. & $57-63$ & 5 & 15,15 \\
\hline & Jumlah & 33 & 100
\end{tabular}

Sumber : Data Primer di olah, Tahun 2019

Tabel 1 di atas memperlihatkan bahwa umur petani pada daerah penelitian yang terbanyak berada pada distribusi kelompok umur $22-28$ tahun dengan frekuensi sebanyak 9 RTP atau sebesar $(27,27 \%)$, sedangkan yang terkecil berada pada distribusi kelompok umur 50 -56 dengan frekuensi sebanyak 1 RTP atau sebesar $(3,03 \%)$. Dapat di simpulkan bahwa masyarakat Petani pada daerah penelitian berada pada kelompok umur produktif, hal ini dinyatakan sesuai dengan 
pendapat Tohir (1983), bahwa kelompok umur produktif berada pada jenjang 15 55 tahun.

\section{Tingkat Pendidikan Petani}

Salah satu indikator yang dapat digunakan untuk mengetahui kualitas sumber daya manusia adalah tingkat pendidikan penduduk, sesuai dengan pendapat Sumardi, et all (1997), kemajuan suatu wilayah ditentukan beberapa faktor penting yang mencakup kualitas sumber daya manusia.Pada daerah penelitian tingkat pendidikan petani dengan tingkat pendidikan yang paling rendah adalah SD dan paling tinggi SMA. Untuk lebih jelasnya distribusi frekuensi petani berdasarkan tingkat pendidikan dapat dilihat pada Tabel 2 berikut.

Tabel 2. Distribusi Frekuensi Petani Berdasarkan Tingkat Pendidikan di Desa Pematang Jering, Tahun 2019

\begin{tabular}{cccc}
\hline No & Tingkat Pendidikan & Frekuensi(RTP) & Persentase $(\%)$ \\
\hline 1. & SD & 21 & 63,64 \\
2. & SMP & 2 & 6,06 \\
3. & SMA & 10 & 30,30 \\
\hline & Jumlah & 33 & 100
\end{tabular}

Sumber : Data Primer di olah, Tahun 2019

Berdasarkan Tabel 2 di atas, dapat dilihat bahwa sebagian besar tingkat pendidikan petani di Desa Pematang Jering adalah berpendidikan SD dengan jumlah frekuensi sebanyak 21 RTP atau sebesar $(63,64 \%)$ dan tingkat pendidikan petani terkecil adalah sebanyak 2 RTP atau (6,06 \%), hal ini menunjukkan bahwa tingkat pendidikan petani di Desa Pematang Jering masih relatif rendah.Rendahnya tingkat pendidikan petani akan berpengaruh terhadap perencanaan dalam pengolahan usahataninya, hal ini akan mempengaruhi tingkat produksi yang dihasilkan petani tersebut. Soeharjo dan Patong (1993) menyatakan bahwa semakin tinggi tingkat pendidikan petani maka kemampuan petani untuk meningkatkan pengolahan usahataninya akan lebih baik terutama dari segi teknologi baru, pemahaman budidaya dan pemasaran. Untuk mengatasi keadaan demikian, maka petani tersebut juga akan memperoleh pendidikan non formal seperti pelatihan atau penyuluhan.

\section{Jumlah Anggota Keluarga Petani}

Jumlah tanggungan keluarga merupakan salah satu faktor yang mempengaruhi keberhasilan berusaha, semakin banyak jumlah tanggungan keluarga maka semakin banyak kebutuhan yang akan dipenuhi oleh petani. Tanggungan keluarga terdiri dari istri, anak serta anggota keluarga lain yang tinggal bersama keluarga dalam sekaligus menjadi tanggung jawab kepala keluarga. Untuk lebih jelassnya distribusi frekuensi petani berdasarkan jumlah anggota keluarga dapat dilihat pada Tabel 3 berikut. 
Tabel 3. Distribusi Frekuensi Petani Berdasarkan Jumlah Anggota Keluarga di Desa Pematang Jering, Tahun 2019.

\begin{tabular}{cccc}
\hline No & Jumlah Anggota Keluarga(Orang) & Frekuensi(RTP) & Persentase(\%) \\
\hline 1 & $1-2$ & 8 & 24,24 \\
2 & $3-4$ & 16 & 48,48 \\
3 & $5-6$ & 8 & 24,24 \\
4 & $7-8$ & 1 & 3,03 \\
5 & $9-10$ & 0 & 0 \\
6 & $11-12$ & 0 & 0 \\
\hline & Jumlah & 33 & 100
\end{tabular}

Sumber : Data Primer di olah, Tahun 2019

Berdasarkan Tabel 3 di atas memperlihatkan bahwa jumlah angoota keluarga petani terbanyak adalah pada kelompok distribusi jumlah anggota keluarga 3-4 orang dengan frekuensi sebanyak 16 RTP atau sebesar $(48,48 \%)$ dan jumlah anggota keluarga petani terkecil adalah sebanyak 1 RTP atau sebesar $(3,03 \%)$, dengan rata-rata jumlah tanggungan keluarga sebanyak 4 orang. Dengan banyaknya jumlah anggota keluarga petani dapat mengurangi tenaga kerja luar dalam melakukan usaha budidaya ikan, namun semakin banyak anggota keluarga petani maka semakin besar pula tanggungan dalam keluarga petani tersebut.

\section{Keramba Petani}

Keramba merupakan media budidaya ikan nila yang dilakukan petani di daerah peneitian, banyak keramba mempengaruhi banyaknya produksi perikanan. Untuk lebih jelasnya distribusi frekuensi petani berdasarkan banyak keramba yang dimilikinya dapat dilihat pada Tabel 4 berikut.

Tabel 4. Distribusi Frekuensi Petani Berdasarkan Banyak Keramba yang dimilikinya di Desa Pematang Jering Tahun 2019.

\begin{tabular}{cccc}
\hline No & Banyak Keramba(Unit) & Frekuensi(RTP) & Persentase $(\%)$ \\
\hline 1 & $8-11$ & 16 & 48,48 \\
2 & $12-15$ & 9 & 27,27 \\
3 & $16-19$ & 3 & 9,09 \\
4 & $20-23$ & 2 & 6,06 \\
5 & $24-27$ & 2 & 6,06 \\
6 & $28-31$ & 1 & 3,03 \\
\hline & Jumlah & 33 & 100 \\
\hline
\end{tabular}

Sumber : Data Primer di olah, Tahun 2019

Berdasarkan Tabel 4 di atas memperlihatkan bahwa petani terbanyak dengan jumlah kepemilikan keramba terdapat pada kelompok distribusi banyak keramba 8 - 11 unit dengan frekuensi sebanyak 16 RTP atau sebesar $(48,48 \%)$, dan jumlah terkecil kepemilikan keramba terdapat pada kelompok distribusi banyak keramba 28 - 31 unit dengan frekuensi 1 RTP atau sebesar $(3,03 \%)$, dilihat dari rata-rata keramba yang dimiliki petani adalah sebanyak 13 unit. 


\section{Pengalaman Berusaha Petani}

Pengalaman petani budidaya ikan nila mempengaruhi terhadap tingkat pengelolaan usaha yang dilakukannya, petani mempunyai cara-cara tersendiri dalam melakukan usahanya. Pengalaman berusaha petani di daerah penelitian berkisar antara 5 - 12 tahun dengan rata-rata pengalaman berusaha 6 tahun. Untuk lebih jelasnya distribusi frekuensi petani berdasarkan pengalaman berusaha dapat dilihat pada Tabel 5 berikut.

Tabel 5. Distribusi Frekuensi Petani Berdasarkan Pengalaman Berusaha di Desa Pematang Jering, Tahun 2019.

\begin{tabular}{cccc}
\hline No & Pengalaman Usaha(Tahun) & Frekuensi(RTP) & Persentase(\%) \\
\hline 1 & $5-6$ & 27 & 81,81 \\
2 & $7-8$ & 3 & 9,09 \\
3 & $9-10$ & 1 & 3,03 \\
4 & $11-12$ & 2 & 6,06 \\
5 & $13-14$ & 0 & 0 \\
6 & $15-16$ & 0 & 0 \\
\hline & Jumlah & 33 & 100
\end{tabular}

Sumber : Data Primer di olah, Tahun 2019

Berdasarkan Tabel 5 di atas memperlihatkan bahwa pengalaman petani dalam melakukan kegiatan budidaya ikan nila sudah cukup lama dan berpengalaman. Dimana pengalaman petani terbanyak berada pada kelompok distribusi pengalaman usaha 5 - 6 tahun dengan frekuensi sebanyak 27 RTP atau sebesar $(81,81 \%)$ dan pengalaman petani terkecil berada pada kelompok distribusi 9 - 10 tahun dengan frekuensi 1 RTP atau sebesar $(3,03 \%)$.

\section{Gambaran Usaha Budidaya Ikan Nila Dalam (KJA) Di Desa Pematang Jering}

Adapun rangkaian kegiatan proses budidaya ikan nila dalam keramba jaring apung di Desa Pematang Jering, Kecamatan Jambi Luar Kota, Kabupaten Muaro Jambi adalah sebagai berikut :

Persiapan keramba jaring apung ikan nila dimulai dengan membuat keramba yang terbuat dari kayu yang diberi jaring dengan ukuran (volume) rata-rata berukuran $24 \mathrm{~m}^{3}(3 \mathrm{~m} \times 4 \mathrm{~m} \times 2 \mathrm{~m})$. Bahan kontruksi keramba jaring apung yang digunakan terbuat dari kayu bulian, dengan menggunakan pelampung yang berbahan drum plastik.

Benih ikan merupakan salah satu faktor penentu keberhasilan budidaya ikan nila dalam keramba jaring apung yang ditentukan oleh : mutu, ukuran maupun jumlah yang ditebar. Pada umumnya petani budidaya di daerah penelitian menggunakan benih ikan nila berasal dari penangkaran benih ikan binaan pemerintah yaitu dari BBI,BBAT Sungai Gelam dan UPR Lubuk Linggau. Ukuran benih yang ditebarkan petani budidaya berukuran rata-rata $8 \mathrm{~cm}-12 \mathrm{~cm}$. Berdasarkan pengakuan petani ukuran benih Ikan Nila yang berukuran terlalu kecil beresiko terhadap lamanya pemeliharaan dan tingginya tingkat mortalitas. Jumlah benih yang ditebarkan per unit keramba jaring apung adalah 5.000 ekor 
dengan kisaran ukuran benih $8 \mathrm{~cm}-12 \mathrm{~cm}$, dengan ukuran keramba jaring apung $\left(24 m^{3}\right) 3 m \times 4 m \times 2 m$.

Pakan yang digunakan pada usaha budidaya ikan nila dalam keramba jaring apung pada bulan pertama dari awal pemeliharaan ikan menggunakan merk pakan sapir, rubi hg-5 dan jatra yang sudah dihaluskan dengan pemberian sebanyak 3 kali sehari, setelah satu bulan pertama baru di beri pakan sebanyak 2 kali sehari yang berupa bentuk butiran.

Lama Pemeliharan tergantung jenis ikan dan permintaan pasar. Rata-rata lama pemeliharaan adalah 180 hari (6 bulan) dengan berat rata-rata produksi dalam satu kali periode adalah 616,67 Kg/Keramba.

Proses panen ikan dalam budidaya keramba jaring apung tidak terlalu sulit, dengan hanya mengangkat jaring menggunakan bambu panjang yang besar dan kuat, diletakkan dibawah jaring yang akan di panen lalu ditarik kepermukaan setelah itu didorong atau digeser ke sisi dimana ikan akan di timbang dan di packing. Setelah proses diatas selesai, dilakukan penyortiran ikan menggunakan serok guna untuk memisahkan ikan berdasarkan ukuran, sehingga akan memudahkan pada saat packing . Panen dilakukan pada pagi hari sebelum matahari tinggi dan sebelum ikan diberi makan, guna untuk menjaga agar ikan tidak mati saat pengangkutan. Tahap terakhir pada pemanenan adalah penimbangan, pengepakan ikan kedalam kantong plastik beroksigen yang telah disediakan oleh pedagang dan dilakukan pada saat sore atau malam hari, ketika cuaca sudah teduh sehingga ikan tidak mengalami tekanan panas dalam perjalanan.

Rata-rata harga jual ikan nila pada tingkat petani adalah Rp.22.000,-/Kg. ikan hasil produksi dari petani, oleh pedagang dipasarkan ke Kota Jambi (Pasar Angso Duo, Talang Banjar, Keluarga, Talang Gulo, Aur Duri, Sarolangun, Serensen (Tembilahan) dan Pasar Muaro Bulian Serta Sekitar Kabupaten Muaro Jambi.

Menurut beberapa sumber, salah satu dampak positif dari berkembangnya budidaya ikan dalam keramba jaring apung beberapa tahun terakhir ini di Desa Pematang Jering Kecamatan Jambi Luar Kota adalah munculnya lapangan kerja baru dan usaha baru bagi masyarakat disekitar desa sebagai pedagang pengecer.

Di lapangan terlihat bahwa pada umumnya petani di Desa Pematang Jering sudah memahami dan menerapkan teknologi budidaya ikan di keramba jaring apung secara semi intensif, walaupun belum optimal. Indikasi ini antara lain terlihat dari (1) pemahaman petani budidaya ikan dalam menggunakan benih ikan nila yang bermutu, (2) kemampuan dan keterampilan petani budidaya dalam menggunakan dan menghitungkan jumlah pakan ikan sesuai dengan tujuan produksi, (3) Pemahaman petani terhadap benih dan pakan ikan jenis tertentu yang mereka anggap memberi keuntungan lebih besar.

\section{Pendapatan Usaha Budidaya Ikan Nila Dalam Keramba Jaring Apung Produksi}

Di dalam penelitian ini yang dimaksud dengan produksi adalah produk dalam bentuk fisik (ikan nila) yang dihasilkan dari usaha budidaya ikan dalam keramba jaring apung dalam waktu satu periode pemeliharaan yang diukur dalam

Diterbitkan oleh Program Studi Agribisnis Fakultas Pertanian Universitas Batanghari Jambi Halaman 91 
satuan $(\mathrm{Kg})$.Dari hasil penelitian dapat diketahui bahwa produksi ikan nila yang dihasilkan petani berkisar $500 \mathrm{Kg}$ sampai $700 \mathrm{Kg}$ per periode pemeliharaan. dengan rata-rata sebesar $616,67 \mathrm{Kg} / \mathrm{Keramba}$. Distribusi frekuensi berdasarkan jumlah produksi ikan dapat dilihat pada Tabel 6 berikut ini :

Tabel 6. Distribusi Frekuensi Petani Berdasarkan Produksi Ikan Nila KJA per Unit Keramba di Desa Pematang Jering Tahun 2019.

\begin{tabular}{cccc}
\hline No. & Distribusi Produksi (Kg/Keramba) & Frekuensi (RTP) & Persentase $(\%)$ \\
\hline 1. & $500-533$ & 11 & 33,33 \\
2. & $534-567$ & 0 & 0 \\
3. & $568-601$ & 0 & 0 \\
4. & $602-635$ & 0 & 0 \\
5. & $636-669$ & 11 & 33,33 \\
6. & $670-703$ & 11 & 33,33 \\
\hline & Jumlah & 33 & 100 \\
\hline
\end{tabular}

Sumber : Data Primer di olah, Tahun 2019

Tabel 6 di atas memperlihatkan bahwa distribusi produksi ikan sebagian besar berada pada kisaran $500-533 \mathrm{Kg}, 636-669 \mathrm{Kg}, 670-703 \mathrm{Kg}$.Dengan frekuensi masing-masing sebanyak $11 \mathrm{RTP}(33,33 \%)$.

\section{Biaya Produksi}

Biaya produksi ikan adalah jumlah pengeluaran yang terdiri dari biaya variabel dan biaya tetap. Pada usaha budidaya keramba jaring apung yang termasuk biaya variabel adalah : (1) biaya pembelian sarana produksi (benih, pakan, vitamin dan obat-obatan), sedangkan biaya tetap adalah biaya penyusutan yang di hitung berdasarkan nilai ekonomisnya yaitu keramba, jaring, baut, tali, drum, serok, timbangan,keranjang. Untuk lebih jelasnya komponen dari biaya masing-masing produksi dapat dilihat pada Tabel 7 berikut ini :

Tabel 7. Rata-Rata Biaya Produksi Usaha Budidaya Ikan Nila Per Periode Pemeliharaan Di Desa Pematang Jering Tahun 2019.

\begin{tabular}{|c|c|c|c|}
\hline No. & $\begin{array}{l}\text { Komponen } \\
\text { Biaya Produksi }\end{array}$ & $\begin{array}{l}\text { Jumlah } \\
\text { (Rp/Periode) }\end{array}$ & Persentase (\%) \\
\hline \multirow[t]{10}{*}{1.} & Biaya Tetap & & \\
\hline & - Keramba & $3.318 .181,82$ & 3,36 \\
\hline & - $\quad$ Jaring & $1.725 .454,55$ & 1,75 \\
\hline & - $\quad$ Timbangan & $22.818,18$ & 0,02 \\
\hline & - $\quad$ Keranjang & $13.554,55$ & 0,01 \\
\hline & - Drum & $724.848,48$ & 0,73 \\
\hline & - $\quad$ Baut & $99.545,45$ & 0,10 \\
\hline & - $\quad$ Tali & $19.909,09$ & 0,02 \\
\hline & - $\quad$ Serok & $8.776,52$ & 0,01 \\
\hline & Jumlah I & 5.933.088,64 & 6 \\
\hline \multirow[t]{5}{*}{2.} & Biaya Tidak Tetap & & \\
\hline & - Benih & $15.595 .454,55$ & 15,77 \\
\hline & - $\quad$ Pakan & $76.832 .266,67$ & 77,71 \\
\hline & - Obat-obatan & $53.090,91$ & 0,05 \\
\hline & - $\quad$ Vitamin & $456.858,18$ & 0,46 \\
\hline \multicolumn{2}{|r|}{ Jumlah II } & 92.937.670,31 & 93,99 \\
\hline \multicolumn{2}{|r|}{ Jumlah I + II } & 98.870.758,95 & 100 \\
\hline
\end{tabular}


Tabel 7 di atas terlihat bahwa rata-rata jumlah total biaya produksi yang digunakan petani pada budidaya ikan nila keramba jaring apung sebanyak Rp.98.870.758,95,- per periode, dengan biaya produksi terkecil pada komponen biaya tetap yaitu Rp.5.933.088,64,-/periode atau sebesar (6 \%). Sedangkan yang terbesar adalah pada biaya tidak tetap yaitu sebesar Rp.92.937.670,31,-/periode atau sebesar $(93,99 \%)$.

\section{Penerimaan Usaha Budidaya Ikan Nila}

Penerimaan petani budidaya ikan nila KJA lebih jelas nya dapat dilihat pada Tabel 8 berikut ini :

Tabel 8. Rata-rata Penerimaan Usaha Budidaya Ikan Nila dalam KJA per Unit per Periode Pemeliharaan di Desa Pematang Jering Tahun 2019.

\begin{tabular}{ccc}
\hline Uraian & Satuan & Jumlah \\
\hline Jumlah Produksi & Kg/Periode & 8.178 .79 \\
Harga Jual & Rp/Kg & 22.000 \\
Penerimaan & Rp/Periode & $179.933 .380,00$ \\
\hline
\end{tabular}

Harga jual ikan nila yang berlaku di tingkat petani pada tahun 2019 rata-rata Rp.22.000,-/Kg. Dengan rata-rata keramba 13 unit dapat memproduksi rata-rata ikan nila di daerah penelitian dalam satu periode adalah 6 bulan, dengan berat pada akhir pemeliharaan (Panen) adalah berkisar antara $300-500$ gram/ekor atau lebih, Jumlah rata-rata penerimaan dari penjualan ikan nila selama satu periode adalah Rp.179.933.380,00,-

\section{Pendapatan}

Pendapatan usaha budidaya adalah selisih antara total penerimaan dengan biaya usaha budidaya. Hasil pendapatan usaha budaya ikan nila dalam keramba jaring apung di Desa Pematang .Jering dapat dilihat pada Tabel 9.

Tabel 9. Rata-rata Pendapatan Petani Dari Usaha Budidaya Ikan Nila Dalam (KJA) Per Unit Keramba Per Periode Di Desa Pematang Jering Tahun 2019.

\begin{tabular}{ccc}
\hline No. & Uraian & Jumlah (Rp) \\
\hline 1. & Penerimaan & $179.933 .380,00$ \\
2. & Total Biaya Produksi & $98.870 .758,95$ \\
3. & Pendapatan & $81.062 .621,05$ \\
\hline
\end{tabular}

Tabel 9 di atas memperlihatkan bahwa dengan total biaya sebesar Rp.98.870.758,95,- untuk kegiatan usaha budidaya ikan nila dalam keramba jaring apung dapat menghasilkan pendapatan usaha budidaya petani dan keluarganya sebesar Rp.81.062.621,05,- per periode pemeliharaan. Dengan rata-rata penerimaan sebesar Rp. 179.933.380,00,-- 


\section{KESIMPULAN}

Berdasarkan penelitian yang dilakukan, dapat diambil kesimpulan diantaranya :

1. Gambaran dari usaha Budidaya Ikan Nila dalam keramba jaring apung adalah ukuran keramba rata-rata $3 \mathrm{~m} \times 4 \mathrm{~m} 2 \mathrm{~m}\left(24 \mathrm{~m}^{3}\right)$, dengan padat penebaran benih rata-rata 5.000 ekor, lama pemeliharaan 180 hari ( 6 bulan) dengan frekuensi pemberian pakan 2 kali sehari. Proses panen ikan dalam budidaya keramba jaring apung dilakukan 1 kali panen dalam 6 bulan/per periode.

2. Usaha Budidaya Ikan Nila dalam keramba jaring apung dengan mengorbankan biaya-biaya yang terdiri dari biaya tetap rata-rata sebesar Rp.5.933.088,64.-. Sedangkan biaya tidak tetap rata-rata sebesar Rp.92.937.670,31.- dalam satu periode pemeliharaan. Total biaya yang dikeluarkan petani untuk per periode pemeliharaan rata-rata sebesar Rp.98.870.758,95-. Produksi ikan nila yang dihasilkan petani dalam satu periode pemeliharaan rata-rata sebesar 616,67 $\mathrm{Kg} / \mathrm{unit}$ keramba jaring apung. Penerimaan usaha budidaya ikan nila dalam keramba jarng apung dalam satu periode pemeliharaan sebesar Rp.179.933.380,00.- untuk per unit keramba jaring apung. Pendapatan usaha budidaya ikan nila dalam keramba jaring apung rata-rata sebesar Rp. 81.062.621,05,- unit keramba jaring apung dalam satu periode pemeliharaan.

\section{DAFTAR PUSTAKA}

Bayu P. 2017. Perbandingan Aspek Ekonomi Usahatani Padi Sawah (Oriza Satival) Sistem Tanam Jajar LEGOWA DENGAN Sistem Tegal Desa Pudak Kecamatan Kumpe Ulu Kabupaten Muaro Jaambi [Skripsi]. Fakultas Pertanian. Universitas Batanghari

Boediono. (1992). Teori Pertumbuhan Ekonomi. Yogyakarta, Balai Penelitian Fakultas Ekonomi Universitas Gajah Mada

Dinas Kelautan dan Perikanan Provinsi Jambi. 2018. Jumlah Produksi dan Nilai Budidaya Dalam Kolam, Keramba, Sawah, dan Tambak Menurut Jenis Ikan di Provinsi Jambi 2017

Singarimbun, Masri.1995. Metode Penelititan Survei. LP3S, Jakarta

Soeharjo. A dan Dahlan Patong. 1973. Sendi-Sendi Pokok Imu Usahatani. Depatermen Ilmu-Ilmu Sosial Ekonomi. Institut Pertanian Bogor, Bogor.

Sudarman A. Algifari. 2001. Ekonomi Mikro-Makro. BPFE. Yogyakarta

Sugiyono. 2011. Metode Penelitian Kuantitatif, Kualitatif dan R\&D. Bandung: Afabeta

Sumardi et all 1983. Peranan nilai budaya daerah dalam upaya pelestarian lingkungan hidup di daerah istimewa Yogyakarta. Dirjen kebudayaan. Yogyakarta.

Tohir, Kaslan. 1983. Usahatani Indonesia. Jakarta : Rineka Cipta.

Winarno. 1994. Sterilisasi Komersial Produk-produk Pangan. Jakarta, Gramedia. 